\title{
PERANCANGAN SISTEM INFORMASI APLIKASI E- LEARNING BERBASIS WEB DI SMA N 9 PADANG
}

\author{
Karlina Aisah , Heri Yanto , Firdaus \\ Universitas Putra Indonesia Yptk Padang 1, Indonesia \\ karlinaaisah18@gmail.com
}

\begin{abstract}
Abstrak
E- learning atau electronic learning merupakan konsep pembelajaran yang dilakukan melalui jaringan media elektronik. Perkembangan teknologi yang sangat maju di era modern dan globalisasi memungkinkan berbagai kegiatan dilakukan secara cepat dan efisien. Perkembangan teknologi sudah banyak memberi pengaruh terhadap cara hidup kita, salah satunya adalah dalam bidang pendidikan dengan penggunaan e- learning dalam kegiatan pembelajaran di sekolah, perguruan tinggi, tempat - tempat kursus bahkan komunitas - komunitas online sudah mulai menggunakan konsep seperti ini. Seiring dengan perkembangan teknologi informasi dan tuntutan globalisasi pendidikan serta pembelajaran jarak jauh, berbagai konsep telah dikembangkan untuk menggantikan metode pembelajaran tradisional, salah satunya adalah konsep e- learning. E- learning dapat digunakan sebagai alternatif atas permasalahan dalam bidang pendidikan, baik sebagai tambahan, pelengkap maupun pengganti ataskegiatan pembelajaran yang sudah ada. Dengan penggunaan e- learning dalam proses pembelajaran pada SMA N 9 Padang, diharapkan akan mempermudah siswa dalam kegiatan belajar. Berdasarkan latar belakang tersebut, maka dirancang aplikasi pembelajaran e- learning dengan Learning Management System. Dilihat dari kenyataan tersebut, diperlukan suatu sarana penunjang yang mampu meningkatkan efektivitas dan efisiensi dalam system mengajar di SMA N 9 PADANG dalam meningkatkan pembelajaran terhadap siswa.
\end{abstract}

Kata Kunci : Sistem Informasi, Web, E-Learning

\section{PENDAHULUAN}

E- learning atau electronic learning merupakan konsep pembelajaran yang dilakukan melalui jaringan media elektronik. Perkembangan teknologi yang sangat maju di era modern dan globalisasi memungkinkan berbagai kegiatan dilakukan secara cepat dan efisien. Perkembangan teknologi sudah banyak memberi pengaruh terhadap cara hidup kita, salah satunya adalah dalam bidang pendidikan dengan penggunaan e- learning dalam kegiatan pembelajaran di sekolah, perguruan tinggi, tempat - tempat kursus bahkan komunitas komunitas online sudah mulai menggunakan konsep seperti ini. Seiring dengan perkembangan teknologi informasi dan tuntutan globalisasi pendidikan serta pembelajaran jarak jauh, berbagai konsep telah dikembangkan untuk menggantikan metode pembelajaran tradisional, salah satunya adalah konsep e- learning. E- learning dapat digunakan sebagai alternatif atas permasalahan dalam bidang pendidikan, baik sebagai tambahan, pelengkap maupun pengganti ataskegiatan pembelajaran yang sudah ada. Di SMK Syubbanul Wathon merupakan sekolah negeri berakreditasi A, namun sekolah ini belum mempunyai sarana sebagai media pembelajaran online untuk mengelola dan memudahkan dalam penyebaran informasi pembelajaran, maka perlu dibuat suatu system informasi E- Learning berbasis web yang dapat diakseskapan saja dan dimana saja sehingga mendukung proseskegiatan belajar mengajar menjadi lebih efektif. (Maulina Dina, 2017). Studi kasus di SMP Negeri 3 Patuk Gunung Kidul Yogyakarta, masalah yang terjadi di SMP Negeri 3 Patuk Gunung Kidul adalah selama ini prosesbelajar mengajar antara guru dan siswa sangat terbatas. Hanya berkisar selama 1- 2 jam untuk satu mata pelajaran.Interaksi antara guru dan murid juga kurang interaktif. Sehingga jika terjadi kendala, seperti siswa yang kuurang paham mengenai pelajaran tertentu akan kesulitan jika ingin mengulang materi dan betanya kepada guru yang bersangkutan secara langsung. (Eko Wahyu 
Susanto, tahun 2017). Di SMA Yayasan Dharma Bhakti Medan ini yang lebih banyak diberikan teori didalam ruangan kelas daripada praktek diruangan kelas secara umum masih diawasi oleh guru dalam proses pembelajaran, sehingga siswa dapat dikatakan belum mampu meningkatkan pengetahuan, keahlian, prestasi, maupun pengembangan diri sendiri dalam belajar. Dari uraian diatas dapat dilihat bajwa proses pembelajaran disekolah pada siswa SMK maupun SMA di Yayasan Dharma Bhakti Medan masih harus diawasi olrh guru. Untuk dapat meningkatkan pengetahuan dalam proses belajar, maka perlu dibangun suatu system pembelajaran yang memanfaatkan teknologi komputer yaitu dengan menggunakan aplikasi E- Learninng berbasis Web. Perancangan aplikasi ini bertujuan untuk menambah wawasan dan ilmu pengetahuan dalam pengukuti proses belajar yang tidak hanya disekolah saja tetapi dapat diakses melalui internet. Sehingga setiap siswa dapat mengaksess materi pelajaran dan berdiskusi kepada guru melalui ELearning sekolah berbasis Web. (Stimik Stikom,Oktober 2015). Berdasarkan latar belakang penelitian terdahulu, maka penulis memaparkan latar belakang yang penulis dapatkan dari penelitian ini yaitu di SMA N 9 PADANG sekarang sekolah negeri dengan akreditasi A dikota Padang,Sumatera Barat, akan tetapi sarana dan prasarana di Sma ini masih dibilang kurang dibasis teknologi dan informasi, system pembelajaran di sma ini masih tradisional yaitu dengan tatap muka. Dengan seiring berjalanya waktu pendidikan satu persatu telah memgunakan situs belajar online atau bisa disebut E- Learning. Metode belajar dengan online ini sangatlah efiien dan menghemat waktu serta memperluaswawasan siswa terhadap teknologi. Dengan penggunaan elearning dalam proses pembelajaran pada SMA N 9 Padang, diharapkan akan mempermudah siswa dalam kegiatan belajar. Berdasarkan latar belakang tersebut, maka dirancang aplikasi pembelajaran e- learning dengan Learning Management System. Dilihat dari kenyataan tersebut, diperlukan suatu sarana penunjang yang mampu meningkatkan efektivitas dan efisiensi dalam system mengajar di SMA N 9 PADANG dalam meningkatkan pembelajaran terhadap siswa.

\section{TINJAUAN LITERATUR}

\author{
Konsep Dasar Sistem
}

Sebagai suatu jaringan kerja prosedur yang saling berhubungan, sedangkan pendekatan sistem yang lebih menekankan pada elemen atau komponen mendefinisikan sistem sebagai kumpulan elemen yang beriteraksi untuk mencapai suatu tujuan tertentu (Hutahaean, Jeperson.2015).

Suatu system dapat dirumuskan sebagai setiap kumpulan atau subsistem yang dirancang untuk mencapai tujuan (Sutabri, Tata.2012). Suatu system dapat diartikan sebagai suatu kumpulan atau himpunan dari unsure, komponen, atau variable yang terorganisir, saling berinteraksi, saling tergantung satu sama lain, dan terpadu. Konsep lain yang terkandung didalam definisi tentang system adalah konsep sinergi. Konsep ini mengandalkan bahwa didalam suatu system , output dari suatu organisasi diharapkan lebih besar dari pada output individual atau output masing-masing bagian. Kegiatan bersama dari bagian yang terpisah tetapi saling berhubungan secara bersama-sama akan menghasilkan efek total yang lebih besar daripada jumlah bagian secara individu dan terpisah (Elausta, Andre.2017)

Sistem informasi juga mempunyai karakteristik. Karakteristik dari sistem adalah (Sutabri, Tata.2013):

\section{1) Komponen Sistem (Components)}

Suatu sistem terdiri dari sejumlah komponen yang saling berinteraksi, yang bekerja sama membentuk satu kesatuan. Komponen-komponen sistem tersebut dapat berupa suatu bentuk subsistem.

\section{2) Batasan Sistem (Boundary)}

Ruang lingkup sistem merupakan daerah yang membatasi antara sistem dengan sistem lainnya atau sistem dengan lingkungan luarnya. Batasan sistem ini memungkinkan suatu sistem dipandang sebagai satu kesatuan yang tidak dapat dipisahpisahkan.

\section{3) Lingkungan Luar Sistem (Environtment)}


Lingkungan luar sistem adalah bentuk apapun yang ada di luar ruang lingkup atau batasan sistem yang mempengaruhi operasi sistem tersebut.

\section{4) Penghubung Sistem (Interface)}

Penghubung sistem atau interface adalah media yang menghubungkan sistem dengan subsistem yang lain.

\section{5) Masukan Sistem (Input)}

Energi yang dimasukkan ke dalam sistem disebut masukan sistem, yang dapat berupa pemeliharaan (maintenance input) dan sinyal (signal input).

\section{6) Keluaran Sistem (Output)}

Keluaran ini merupakan masukan bagi subsistem yang lain. Seperti contoh sistem informasi, keluaran yang dihasilkan adalah informasi, di mana informasi ini dapat digunakan sebagai masukan untuk pengambilan keputusan atau hal-hal lain yang merupakan input bagi subsistem lain.

\section{7) Pengolah Sistem (Process)}

Suatu sistem dapat mempunyai suatu proses yang akan mengubah masukan menjadi keluaran.

\section{8) Sasaran Sistem (Objective)}

Suatu sistem memiliki tujuan dan sasaran yang pasti dan bersifat deterministik.

Sistem Informasi adalah data yang telah diklasifikasikan atau diolah atau interpretasikan utnuk digunakan dalam proses pengambilan keputusan (Sutabri, Tata.2013).

Menurut Mc Leod Informasi adalah data yang diolah menjadi bentuk lebih berguna dan lebih berarti bagi yang menerimanya. Informasi merupakan data yang telah di proses demikian rupa sehingga meningkatkan pengetahuan seseorang yang menggunakan. Sistem apapun tanpa informasi tidak akan berguna, karena sistem tersebut akan mengalami kemacetan dan akhirnya berhenti (Arifard, Watung, Ivan dkk.2014). Informasi dapat berupa mentah, data tersusun, kapasitas sebuah saluran informasi, dan sebagainya. Sumber dari informasi adalah data. Data merupakan bentuk jamak dari bentuk tunggal datum atau data-item.
Data adalah kenyataan yang menggambarkan suatu kejadian-kejadaian dan kesatuan nyata. Kejadiankejadian (event) adalah suatu yang terjadi pada saat yang tertentu (Arifard, Watung, Ivan dkk.2014).

Kejadian-kejadian (event) merupakan suatu yang terjadi pada saat yang tertentu.Kesatuan nyata (fact) merupakan suatu obyek nyata seperti tempat, benda, dan orang yangbetul-betul ada dan terjadi (Aini, Anisa.2013).

Pada umumnya tujuan melakukansuatu perancangan sistem informasi adalah:

1) Untuk memenuhi kebutuhan pemakai sistem informasi.

2) Untuk memberikan gambaran yang jelas dan rancang bangun lengkap kepada programmer.

3) Untuk mendukung pengolahan pelaporan data pada organisasi ataupun sekolah.

Media pembelajaran adalah alat bantu proses belajar mengajar yang segala sesuatu dapat dipergunakan untuk merangsang pikiran, perasaan, perhatian dan kemampuan atau ketrampilan pelajar sehingga dapat mendorong proses belajar mengajar antara siswa dan guru (Arsyad, Azhar.2011).

E-Learning adalah sebuah bentuk teknologi informasi yang diterapkan dibidang pendidikan berupa website yang dapat diakses dimana saja dan kapan saja. E-Learning merupakan dasar dan konsekuensi logis dari perkembangan teknologi informasi dan komunikasi (Wahono, Romi.2003)

\section{Tujuan E-Learning}

Tujuan E-Learninh antara lain yaitu meningkatkan daya serap dari para pengguna atas materi yang diajarkan, meningkatkan partisipasi aktif dari para siswa, meningkatkan kemampuan belajar mandiri melalui website serta meningkatkan kualitas materi pembelajaran. Diharapkan dapat merangsang pertumbuhan inovasi baru para pengguna sesuai dengan bidang masing-masing(Wahono, Romi.2003).

Data berasal dari DATUM yang berarti materi atau kumpulan fakta yang dipakai untuk keperluan suatu analisa, diskusi, presentasi ilmiah, atau tes statistik. 
Bila dilihat menurut asal sumbernya, data dibagi menjadi 2 kelompok, yaitu data primer dan data sekunder. Sehingga setiap penelitian pasti memerlukan data sebagai bahan analisa (Kusuma, Abdi Pandu dan Tedhi, Widodo. 2016). Data adalah kenyataan yang menggambarkan suatu kejadian-kejadian dan kesatuan nyata. Menurut John J. Longkutoy dalam bukunya Pengenalan Komputer mendefinisikan bahwa istilah data dalah suatu istilah majemuk yang berarti fakta atau bagian dari fakta yang mengandung arti yang dihubungkan dengan kenyataan, simbol-simbol, gambar-gambar, angka-angka, huruf-huruf, atau simbol-simbol yang menunjukkan suatu ide, objek, kondisi, atau situasi lain (Sutabri, Tata. 2013)

Untuk menggambarkan system yang dianalisa, penulis menggunakan, alat Bantu perancangan system yang baku, berupa Data Flow Diagram (DFD) atau bisa disebut juga Diagram Aliran Data (DAD), system Flowchart, Entity Relationship Diagram (ERD), kamus data, spesifikasi proses.

UML merupakan bahasa visual untuk pemodelan dan komunikasi, mengenai sebuah sistem dengan menggunakan diagram dan teks-teks pendukung. UML hanya berfungsi untuk melakukan pemodelan. Jadi pengunaan UML tidak terbatas pada metodologi tertentu, meskipun pada kenyataannya UML palingbanyak digunakan pada metodologi berorientasi objek.

\section{Class Diagram}

Diagram kelas atau class diagram menggambarkan struktur sistem dari segi pendefinisian kelas-kelas yang akan dibuat untuk membangun sistem (A.S, Rosa dan M. Shalahuddin. 2014).

\section{METODOLOGI}

\section{Kerangka Penelitian}

Kerangka penelitian merupakan konsep atau tahapan- tahapan yang akan dilakukan dalam penelitian. Agar langkah- langkah yang diambil penulis dalam perancangan ini tidak keluar dari pokok pembahasan dan lebih mudah dipahami, maka urutan langkah- langkah penelitian akan dibuat secara sistematis sehingga dapat dijadikan pedoman yang jelas dan mudah untuk menyelesaikan permasalahan yang ada. Adapun kerangka penelitian yang penulis lakukan dalam penelitian yang akan diuraikan pada penjelasan berikut.

\section{Penelitian Pendahuluan}

Penelitian pendahuluan adalah langkah awal dalam melakukan penelitian. Dalam tahap ini berisi latar belakang, ruang lingkup penelitian dan manfaat penulisan, tujuan umum sekolah, sejarah sekolah, struktur organisasi, beserta deskripsi tugas masingmasing bagian dalam sekolah dan mengidentifikasi permasalahan yang ada. Dengan penelitian pendahuluan dapat memberikan bukti awal bahwa masalah yang akan kita teliti di lapangan benarbenar ada. Penelitian ini dilakukan dengan cara survey kelapangan dan pengumpulan data sebelum melakukan penelitian lebih lanjut terhadap objek penelitian.Oleh sebab itu dibutuhkan waktu untuk pengambilan data, waktu penelitian, tempat penelitian, metode penelitian, penelitian lapangan, riset perpustakaan, dan penelitian labor.

\section{Survei Penelitian (StudyLitelatur)}

Pengumpulan data dilakukan dengan membaca dan mempelajari buku-buku,jurnal, dan tulisan yang berhubungan dengan penelitian ini. Dalampengumpulan data yang dilakukan dengan menerapkan metode wawancara dengan pihak Penanggung Jawab lapangan Fitria.Spd dan memperoleh dari sekolah tersebut.

\section{Analisa Tujuan Penulisan}

Dalam prosesanalisa terdapat dua tahap analisa yang harusdilakukan.Tahapan tersebut adalah:

\section{a. Analisa Data}

Setelah data berhasil dikumpulkan, maka langkah selanjutnya adalah melakukan analisis terhadap data tersebut. Analisa data merupakan suatu usaha untuk mengaji dan mengolah data yang telah terkumpul sehingga diperoleh suatu kesimpulan yang bermanfaat sesuai dengan tujuan penelitian.

\section{b. Analisa Sistem}

Analisis sistem merupakan dasar dalam merencanakan dan merancang sistem yang akan 
diterapkan.Analisa sistem dilakukan untuk mengetahui dan mengembangkan sistem yang sedang berjalan. Sistem ini memerlukan beberapa data yang harus dicantumkan dalam sebuah sistem yang akan dibuat. Beberapa data yang akan dicantumkan antara lain materi,soal latihan,absensi, dan data-data lainnya.Data tersebut akan dimasukkan dalam database agar terorganisasi dengan baik.

\section{PERANCANGAN}

Tahapan perancangan bertujuan untuk membuat penelitian dirancang sesuai dengan tujuannnya, sehingga tidak melenceng dari tujuan penelitian. Akan dilakukan proses pengumpulan data- data yang akan dilakukan untuk mendukung perancangan sistem sebagai objek penelitian. Perancangan akan menggunakan UML (Unified Modeling Languange) sebagai model rancangan

agar terorganisasi dan terstruktur dengan rancangan.

Penerapan (Implementasi)

Implementasi ini dilakukan untuk mengetahui spesifikasi komputer untuk menjalankan program dan software apa saja yang dibutuhkan. Merupakan tahap penelitian yang dilakukan untuk mempraktekkan langsung hasil dari analisa yang bertujuan untuk menguji kebenaran proses yang dilakukan secara manual dan dengan program. Program yang digunakan dalam pembuatan akhir ini yaitu web dan database MySql.

\section{Pengujian}

Pengujian merupakan tahapan penelitian yang dilakukan untuk mempraktekkan langsung hasil dari analisa yang bertujuan untuk menguji kebenaran sistem yang dirancang dengan cara memfokuskan pada Fungsionalitas dan aplikasi data mining yang meliputi kesalahan fungsi,interface, dan basisdata:

\section{a. Pengujian aplikasi}

1. aplikasi yang dibuat di uji oleh penulisterlebih dahulu.
2. aplikasi digunakan secara umum oleh user/admin, siswa, dan guru.

3. aplikasi djalankan melalui bahasa pemograman web

\section{HASIL DAN DISKUSI}

Anda dapat memasukan hasil dan catatan diskusi. Hasilnya disajikan dalam format yang dapat diakses oleh pembaca (misalnya dalam grafik, tabel, diagram atau teks tertulis). Perhatikan bahwa data mentah biasanya dimasukkan dalam lampiran.

\section{Halaman Forum}

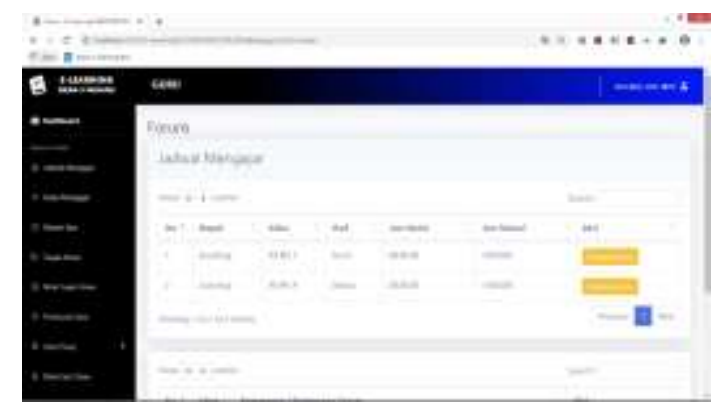

Gambar 1: Halaman Forum

Halaman ini berguna untuk menampilkan data forum.

\section{Halaman Login}

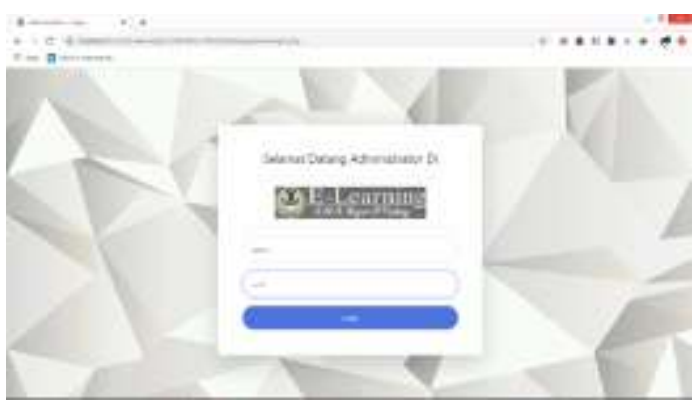

Gambar 2: Halaman Login

Halaman login digunakan untuk dapat masuk ke dalam sistem. 


\section{Halaman Laporan Guru}

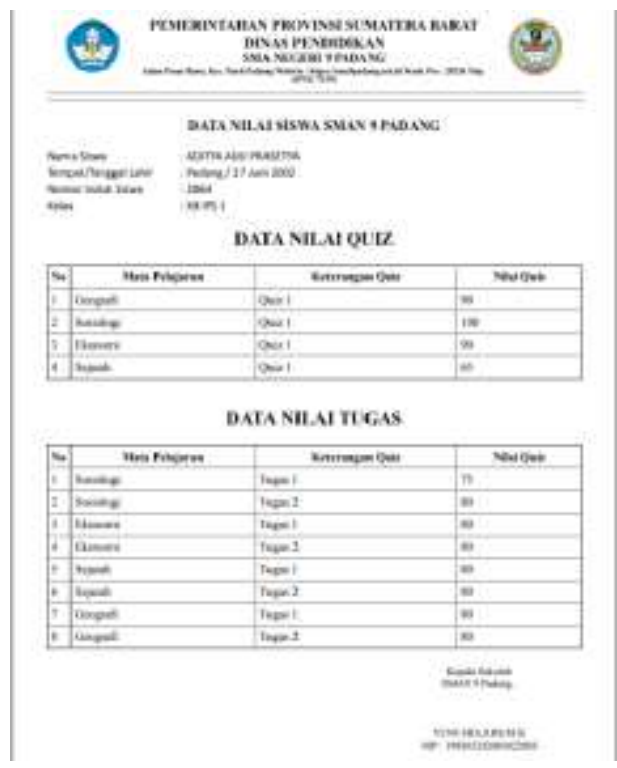

Gambar 3: Halaman Laporan Nilai Siswa Oleh Guru

Pada tampilan laporan data guru, admin dapat mencetak laporan guru. Pada tampilan laporan data nilai siswa, admin dapat mencetak laporan nilai siswa

\section{KESIMPULAN}

Berdasarkan hasil pembahasan yang telah diuraikan pada bab- bab sebelumnya, maka penulis dapat menarik kesimpulan sebagai berikut :

1. Dengan adanya rancangan system informasi E- learning berbasis web ini diharapkan siswa dan siswi serta guru dapat dengan mudah untuk memdapatkan informasi tentang pembelajaran, serta informasi- informasi dari sekolah tanpa harus bertatap muka ataupun mendatangi sekolah.

2. Dengan adanya Sistem Informasi Elearning berbasis web ini maka proses pembuatan laporan, penginputan nilai, soal, quis dan yang lainnya bagi guru dapat dilakukan dengan mudah dan lebih efisien, dan diharapkan dapat mengurangi kesalahan serta dapat dilakukan dimana saja dan kapan saja.
3. Aplikasi E- Learning memudahkan guru dalam mendistribusikan tugas dan memudahkan siswa dalam mengumpulkan tugas serta menngerjakan ulangan secara online yang dibuat oleh guru

4. Aplikasi ini dapat dijadikan sarana bertukar informasi dan diskusi antara guru dan siswa serta siswa dan siswa

5. Aplikasi E- learning tidak sulit untuk digunakan, karna dalam aplikasi E- learning yang di buat penulis sangat mudah dipahami dan dimengerti oleh guru dan siswa

\section{DAFTAR PUSTAKA}

[1] H. Memon, I. A. Rahman, M. R. Abdullah, and A. A. A. Azis, "Factors Affecting Construction Cost in Mara Large Construction Project: Perspective of Project Management Consultant," International Journal of Sustainable Construction Engineering \& Technology, vol. 1, 40-53, 2010.

[2] J. Cohen, "Statistical power analysis for the behavioral sciences," 2nd ed., 1988.

[3] Z. M. Daud, M. H. Ahmad, and F. Yusof, "Elementary Statistics," Preatice Hall, Pearson (M) SdnBhd, 2009.

[4] T. Herawan, M.M. Deris, and J.H. Abawajy, "A Rough Set Approach for Selecting a Clustering Attribute," Knowledge Based Systems, Volume 23, Issue 3, 220-231, 2010.

[5] Khamidah, K., \& Triyono, R. A. (2013). Pengembangan Aplikasi e-Learning Berbasis Web Dengan PHP Dan My SQL Studi Kasus SMPN 1 Arjosari. IJNS-Indonesian Journal on Networking and Security, 2(2)

[6] Robbi, M. S., \& Yulianti, Y. (2019). Perancangan Aplikasi E-Learning Berbasis Web dengan Model Prototype pada SMPN 7 Kota Tangerang Selatan. Jurnal Teknologi Sistem Informasi dan Aplikasi, 2(4), 148-154.

[7] Wassalam, O. J. F., Umar, R., \& Yudhana, A. (2017). Implementasi Dan Pengembangan Sistem E-Learning Berbasis Web Pada Stimik Muhammadiyah Paguyangan.

[8] Batubara, F. R. (2019). Perancangan dan implementasi aplikasi e-learning versi mobile berbasis android.

[9] Putra, A. B. (2019, October). Perancangan dan Pembangunan Sistem Informasi ELearning Berbasis WEB (Studi Kasus Pada Madrasah Aliyah Kare Madiun). In Prosiding 
Jurnal KomtekInfo, Vol.8 No.1 Tahun 2021

e-ISSN : $\underline{2502-8758}$ || p-ISSN : 2356-0010

DOI : $10.35134 /$ komtekinfo.v7i4

Page : 66-72

Seminar Nasional Teknologi Informasi dan Komunikasi (SENATIK) (Vol. 2, No. 1, pp. 81-85).

[10] Andry, J., \& Stefanus, M. (2020). Pengembangan aplikasi E-learning Berbasis web menggunakan model waterfall pada SMK Strada 2 Jakarta. Jurnal Fasilkom, 10(1), 110. 